\title{
PENGARUH BUDAYA ORGANISASI DAN ROTASI PEKERJAAN TERHADAP MOTIVASI KERJA UNTUK MENINGKATKAN KINERJA PEGAWAI
}

\author{
Ilma Megantara1; Suliyanto²; Ratno Purnomo ${ }^{3}$ \\ Program Pascasarjana Magister Manajemen Universitas Jenderal Soedirman Purwokerto \\ Fakultas Ekonomi dan Bisnis Magister Manajemen Universitas Jenderal Soedirman \\ Purwokerto \\ Email corresponding author : $\underline{\text { Imamegantara85@gmail.com }}$
}

\begin{abstract}
Abstrak
Penelitian ini bertujuan untuk melihat apakah ada pengaruh dari variabel budaya organisasi, rotasi pekerjaan, dan motivasi kerja terhadap kinerja pegawai di PT. Jasa Raharja Cabang Jawa Tengah. Jumlah sampel yang digunakan sebanyak 62 pegawai Teknik pengambilan sampel yang digunakan adalah random sampling. Penelitian ini menggunakan pendekatan kuantitatif dengan teknik analisis jalur dengan software SPSS 17. Hasil analisis menunjukkan bahwa budaya organisasi tidak berpengaruh terhadap motivasi kerja, rotasi pekerjaan berpengaruh terhadap motivasi kerja, budaya organisasi tidak berpengaruh terhadap kinerja pegawai, rotasi pekerjaan berpengaruh terhadap kinerja pegawai, motivasi kerja berpengaruh terhadap kinerja pegawai. Implikasi manajerial yang dapat dilakukan berkaitan dengan peningkatan kinerja pegawai diantaranya meningkatkan kualitas rotasi pegawai dengan meningkatkan produktivitas dan mempersiapkan karyawan untuk sistem manajemen yang lebih baik serta menyesuaikan pekerjaan dengan kondisi fisik karyawan, kinerja pegawai dapat diukur secara kontinue untuk mengetahui prestasi kerja pegawai serta melakukan evaluasi terhadap pelaksanaan kegiatan dan hasil kinerja untuk menjamin konsistensi.
\end{abstract}

Kata kunci : budaya organisasi, rotasi pekerjaan, motivasi kerja, kinerja pegawai

\begin{abstract}
This study aims to see whether there are influences from organizational culture variables, job rotation, and work motivation on employee performance at PT. Jasa Raharja Central Java Branch. The number of samples used was 62 employees. The sampling technique used was random sampling. This study uses a quantitative approach with path analysis techniques with SPSS 17 software. The results of the analysis show that organizational culture does not affect work motivation, job rotation influences work motivation, organizational culture does not affect employee performance, job rotation affects employee performance, work motivation affect employee performance. The managerial implications that can be made relating to improving employee performance include improving the quality of employee rotation by increasing productivity and preparing employees for better management systems and adjusting work to the physical condition of employees, employee performance can be measured continuously to determine employee performance and evaluate implementation of activities and performance results to ensure consistency.
\end{abstract}

Keywords: organizational culture, job rotation, work motivation, employee performance 


\section{PENDAHULUAN}

Penyelenggaraan pelayanan publik yang dilaksanakan oleh aparatur pemerintah dalam berbagai sektor pelayanan, terutama yang menyangkut pemenuhan hak-hak sipil dan kebutuhan dasar masyarakat, kinerjanya masih belum seperti yang diharapkan. Keberhasilan suatu organisasi dipengaruhi oleh kinerja pegawai (job performance) atau hasil kerja yang dicapai oleh seorang pegawai dalam melakukan tugas sesuai dengan tanggung jawab yang diberikan kepadanya, seorang pegawai yang profesional tidak dapat melepaskan diri dari kenyataan bahwa mereka individu yang mempunyai kebutuhan, keinginan, dan harapan dari tempat bekerjanya. Keinginan untuk memenuhi kebutuhan inilah yang akan mempengaruhi motivasi kerja pada setiap individu untuk melakukan sesuatu yang lebih baik dalam mencapai tujuan. Hasil penilaian kinerja pada tahun 2017 dengan predikat cukup naik menjadi 26,95\% dan predikat kurang menjadi $13,17 \%$, untuk itu perlu adanya cara bagaimana meningkatkan penilaian kinerja menjadi lebih baik dari tahun ketahun.

Permasalahan budaya organisasi yang ada di PT. Jasa Raharja Cab.Jawa Tengah terutama dengan belum optimalnya pemberian pelayanan terhadap masyarakat terkait dengan informasi dan pengurusan klaim asuransi kecelakaan lalu lintas, permasalahan ini secara langsung dapat berdampak pada kinerja pegawai yang menurun. Robbins (2010) kekuatan budaya perusahaan akan menghasilkan kinerja yang baik, sehingga menanamkan nilai-nilai para karyawan. Masrukhin dan Waridin (2006) mengungkapkan bahwa didalam organisasi memiliki budaya organisasi yang berfungsi membentuk aturan dalam berfikir dan bertindak untuk mencapai tujuan. Budaya organisasi yang tumbuh dan terpelihara dengan baik akan mampu memacu organisasi ke arah yang lebih baik. Faktor utama dalam perubahan dan pengembangan budaya organisasi adalah mencoba untuk mengubah nilai-nilai, sikap dan perilaku dari anggota organisasi secara keseluruhan.

Rotasi pekerjaan merupakan salah satu desain pekerjaan serta kebijakan pengembangan sumber daya manusia yang memiliki potensi untuk meningkatkan kinerja karyawan melalui kepuasan kerja (Saravani dan Abbasi, 2013). Motivasi juga turut mempengaruhi kinerja pegawai di PT. Jasa Raharja Cabang Jawa Tengah, untuk meningkatkan kualitas dan prestasi kerjanya, karena kondisi pekerjaan yang monoton dan rendahnya kontribusi karyawan dalam memberikan andil bagi perbaikan kinerja karyawan. Berdasarkan latar belakang yang telah diuraikan diatas, maka penulis bermaksud mengadakan penelitian yang berjudul " Pengaruh Budaya Organisasi dan Rotasi Pekerjaan terhadap Motivasi Kerja untuk meningkatkan Kinerja Karyawan PT. Jasa Raharja (Persero) Cabang Jawa Tengah “ dengan penelitian ini diharapkan dapat menjawab permasalahan yang berkaitan dengan kinerja pegawai PT. Jasa Raharja (Persero) Cabang Jawa Tengah sehingga menjadi lebih baik, serta untuk mengetahui pengaruh pada setiap variabel dimana variabel motivasi sebagai variabel mediasi. 


\section{TINJAUAN PUSTAKA DAN PERUMUSAN HIPOTESIS}

\section{Kinerja Karyawan}

Kinerja merupakan suatu hasil kerja atau keberhasilan dari seorang karyawan secara keseluruhan dengan periode waktu tertentu dalam pencapaian tujuan organisasi yang diharapkan. Menurut Rivai dan Basri (2005) ragam kinerja dipengaruhi oleh dua hal yaitu perubahan lingkungan eksternal dan lingkungan internal. Ragam kinerja akibat perubahan lingkungan eksternal akan lebih sulit diperkirakan karena tidak dapat dikontrol oleh perusahaan. Faktor eksternal yang dapat mempengaruhi ragam kinerja diantaranya letak geografis, etos kerja, etika kerja, kinerja perekenomian, hukum, politik, dan sosial.

Kinerja merupakan salah satu aspek penting dalam organisasi.

Kinerja sering juga disebut sebagai prestasi kerja. Kinerja berasal dari kata dalam bahasa inggris "performance" yang dapat diartikan sebagai "penampilan", "prestasi", "pertunjukkan kerja" dan "pelaksanaan tugas". Salah satu aspek yang menentukan keberhasilan organisasi adalah kinerja dari organisasi itu sendiri. Kinerja adalah sebagai seluruh hasil yang diproduksi pada fungsi pekerjaan atau aktivitas khusus selama periode khusus (Cordoso. 2001). Kinerja (performance) dengan prestasi kerja yaitu proses melalui mana organisasi mengevaluasi atau menilai prestasi kerja karyawan (Handoko. 2002).

\section{Budaya Organisasi}

Budaya organisasi sebagai suatu kerangka kerja yang memuat sikap-sikap, nilai-nilai, norma-norma dan pengharapan-pengharapan bersama yang dimiliki oleh anggotaanggota organisasi (Greenberg dan Baron, 2000). Pendapat lain yang diajukan oleh Furnham dan Gunter (1993) dalam Sunarto (2005), budaya organisasi didefinisikan sebagai keyakinan, sikap dan nilai yang umumnya dimiliki yang timbul dalam suatu organisasi. Budaya organisasi berkaitan dengan perkembangan organisasi, merupakam budaya yang berakar pada sejarah organisasi, diyakini bersama-sama dan tidak mudah dimanipulasi secara langsung (Schenieder, 1996, dalam Cahyono 2005). Menurut Stoner dalam Waridin \& Masrukhin (2006), budaya (culture) merupakan gabungan kompleks dari asumsi, tingkah laku, cerita, mitos, metafora dan berbagai ide lain yang menjadi satu untuk menentukan apa arti menjadi anggota masyarakat tertentu. Robbins (2006), budaya organisasi merupakan suatu sistem makna bersama yang dianut oleh anggota organisasi yang membedakan dari organisasi-organisasi lain. Budaya organisasi merupakan suatu sistem nilai yang didapat dan ditumbuhi kembangkan oleh organisasi yang terbentuk menjadi aturan yang digunakan sebagai pedoman dalam berfikir dan bertindak dalam mencapai tujuan organisasi. Robbins (2006), perubahan budaya dapat dilakukan dengan berbagai cara diantaranya: menjadikan perilaku manajemen sebagai model, menciptakan sejarah baru, simbol dan kebiasaan serta keyakinan sesuai dengan budaya yang diinginkan, menyeleksi, mempromosikan dan mendukung pegawai, menentukan kembali proses sosialisasi untuk nilai-nilai yang baru, mengubah sistem penghargaan dengan nilai-nilai baru, menggantikan norma yang tidak 
tertulis dengan aturan tertulis, mengubah sub budaya melalui rotasi jabatan, dan meningkatkan kerja sama kelompok.

\section{Rotasi Kerja}

Menurut Mathis dan Jakcson (2011) Rotasi Pekerjaan adalah proses pemindahan seseorang dari satu pekerjaan ke pekerjaan yang lain. Sebuah teknik yang digunakan untuk mengurangi kemonotonan suatu rutinitas yang dilakukan karyawan. Setiap perusahaan memiliki kebijakan sendiri dalam penerapan waktu rotasi pekerjaan, ada yang berkala (Mingguan, Bulanan, Tahunan) dan tidak berkala. Keuntungan dari adanya rotasi pekerjaan sendiri adalah mengembangkan kapabilitas seorang karyawan dalam melakukan beberapa pekerjaan yang berbeda (Mathis dan Jackson, 2011). Kaymaz (2010) rotasi pekerjaan akan mengurangi kebosanan, mempersiapkan karyawan untuk sistem manajemen yang lebih baik, serta meningkatkan produktivitas, dan meningkatkan pengetahuan dan keterampilan. Manfaat rotasi pekerjaan tidak hanya dirasakan langsung oleh karyawan, akan tetapi perusahaan juga merasakan manfaat tidak langsung karena karyawan rentang akan keterampilan dan manajemen yang lebih luas, penyesuaian diri karyawan atas perubahan, dan mengisi kekosongan personalia.

Menurut Mansur (2009) rotasi pekerjaan bukan tanpa kekurangan, karena akan meningkat biaya pelatihan, produktivitas akan menurun karena memindahkan karyawan pada posisi baru, adanya penyesuain diri lagi karena adanya karyawan baru dalam sebuah kelompok.Rotasi pekerjaan menurut Jorgensen (2005), dalam Kaymaz (2010) rotasi pekerjaan dapat diartikan sebagai pekerjaan dengan tugas yang berbeda atau dalam posisi yang berbeda pada suatu periode tertentu. Menurut Hasibuan (2002) rotasi pekerjaan memiliki manfaat sebagai berikut : meningkatkan produktivitas, menciptakan keseimbangan antara tenaga dengan komposisi jabatan, memperluas atau menambah pengetahuan karyawan, menghilangkan rasa jenuh atau bosan karyawan terhadap pekerjaan, memberikan perangsang agar karyawan mau meningkatkan karir yang lebih tinggi, untuk pelaksanaan hukuman atau sanksi atas pelanggaran-pelanggaran yang dilakukan karyawan, alat pendorong semangat kerja meningkat melalui persaingan-persaingan terbuka, untuk memberikan pengakuan-pengakuan atas prestasinya, untuk tindakan pengamanan yang lebih baik, untuk menyesuaikan pekerjaan dengan kondisi fisik karyawan, untuk mengatasi perselisihan antar sesama karyawan.

\section{Motivasi Kerja}

Motivasi merupakan dorongan yang datang dari dalam diri manusia yang mengaktifkan, menggerakkan serta mengarahkan perilaku untuk mencapai tujuan karena itu kunci untuk mengerti motivasi adalah memahami hubungan kebutuhan, dorongan dan tujuan (Veithzal Rivai, 2001). Manusia yang mempunyai kebutuhan berprestasi tinggi, mempunyai keinginan yang tinggi, mempunyai keinginan yang tinggi untuk sukses, keinginan ini sama besarnya dengan ketakutannya untuk gagal. Selain itu, menyukai tantangan, berani menghadapi kesulitan, berani mengambil risiko, sanggup mengambil alih tanggung jawab dalam tugas, menyukai keunikan, tangkas, cenderung gelisah, 
senang bekerja keras, tidak takut menghadapi kegagalan apabila itu terjadi, serta cenderung menonjolkan diri (Veithzal, 2001).

Robbins (2006) mendefinisikan motivasi sebagai proses yang menentukan intensitas, arah dan ketekunan individu dalam usaha mencapai sasaran. Meski motivasi umum terkait dengan upaya ke arah sasaran apa saja, dalam konteks organisasi maka motivasi berfokus pada tujuan organisasi agar mencerminkan minat tunggal pegawai terhadap perilaku yang berkaitan dengan pekerjaan.

Menurut Gibson dan Donnelly (1997) motivasi merupakan kekuatan yang mendorong seorang pegawai yang menimbulkan dan mengarahkan perilaku. Jadi lebih lanjut dapat disimpulkan bahwa motivasi merupakan suatu rangkaian kegiatan pemberian dorongan, yaitu bukan hanya kepada orang lain tetapi juga pada diri sendiri dengan harapan akan dapat bertindak kearah tujuan yang diinginkan. Flippo (1993) menyatakan bahwa dampak motivasi yang diinginkan manajemen dari pegawai sangat dipengaruhi oleh penilaian pegawai atas (1) valensi atau nilai yang diharapkan berupa hasil yang dinikmati karena melakukan perilaku yang ditentukan dan (2) kuatnya pengharapan (expectancy) bahwa perilaku itu akan benarbenar merealisasi hasil tersebut. Robbins (2001) mengelompokkan beberapa teori motivasi yang meliputi teori awal motivasi dan teori kontemporer tentang motivasi. Teori awal motivasi adalah teori X dan teori Y serta teori dua faktor. Sedangkan teori kontemporer meliputi teori ERG, teori kebutuhan McClelland, teori evaluasi kognitif, teori penetapan sasaran, teori penguatan, teori hanyut (flow) dan motivasi intrinsik, teori kesetaraan dan teori pengharapan.

\section{Perumusan Hipotesis}

Budaya organisasi adalah suatu sistem nilai yang diperoleh dan dikembangkan oleh organisasi dan pola kebiasaan dan falsafah dasar pendirinya, yang terbentuk menjadi aturan yang digunakan sebagai pedoman dalam berpikir dan bertindak dalam mencapai tujuan organisasi. Hasil penelitian yang dilakukan oleh Koesmono (2005) menunjukkan bahwa budaya organisasi memiliki pengaruh positif dan signifikan terhadap motivasi, dimana pengaruh budaya organisasi terhadap motivasi adalah sebesar 0.680 , begitupun dengan hasil penelitian yang dilakukan oleh Mansur, Tolkah (2009) menunjukan adanya pengaruh positif budaya organisasi terhadap motivasi, mempertegas misi organisasi dengan membuat perencanaan kegiatan agar kegiatan dapat dilaksanakan dan dievaluasi dengan tepat dan melibatkan karyawan dalam setiap kegiatan organisasi.

Dari uraian di atas, maka hipotesis yang diajukan adalah sebagai berikut :

\section{H1 : Budaya organisasi berpengaruh positif terhadap motivasi kerja}

Campion, Cheraskin, dan Stevens (1994) bahwa adanya rotasi pekerjaan meningkatkan pengetahuan dan kemampuan dari pegawai. Rotasi berhubunga dengan penempatan pegawai (staffing) serta pengembangan jenjang karier seorang pegawai. Sejalan dengan itu, Pulich (1989) juga memperkuat bahwa keuntungan atas adanya rotasi pekerjaan adalah memperluas cakupan pekerjaan yang dapat dilakukan pegawai dan sarana untuk 
lebih mengembangkan diri pegawai. Hal ini berarti pegawai akan terdorong untuk bekerja lebih baik dalam mencapai karier yang lebih tinggi. Ofner (1987) menambahkan bahwa dari sisi organisasi, rotasi pekerjaan digunakan untuk menstimulasi pegawai agar dapat mengeluarkan potensi mereka. Pendapat Ortega (2001) semakin mempertegas bahwa rotasi pekerjaan dapat meningkatkan motivasi. Hasil studi lain yang dilakukan oleh Praningrum (2002) menunjukkan bahwa rotasi pekerjaan yang dilakukan dalam suatu organisasi berperan positif dan signifikan dalam meningkatkan motivasi kerja pegawai, Rachmawati (2011) rotasi berpengaruh langsung terhadap motivasi kerja, dimana pada penelitian tersebut rotasi memberikan pengaruh yang dominan terhadap motivasi kerja karyawan.

Dari uraian di atas, maka hipotesis yang diajukan adalah sebagai berikut :

\section{H2 : Rotasi pekerjaan berpengaruh positif terhadap motivasi kerja}

Pada umumnya budaya organisasi banyak dikaitkan dengan kinerja ekonomis jangka panjang. Budaya yang kuat mempunyai implikasi terhadap kinerja yang unggul. Menurut Tjahjadi (2001) berpendapat bahwa kekuatan budaya berkaitan dengan kinerja yaitu penyatuan tujuan; menciptakan motivasi yang kuat, membangun struktur dan kontrol. Menurut Yuwalliatin (2006) menyatakan bahwa perubahan budaya organisasi yang berkesinambungan dapat diciptakan melalui perubahan organisasi. Robbins (2006) dan Hofstede and Bornd (1984) menyatakan bahwa budaya organisasi diukur menggunakan beberapa faktor yaitu profesionalisme kerja, jarak dari manajemen, sikap terbuka pegawai, keteraturan pegawai dan integrasi pegawai. Pada organisasi yang memiliki budaya yang kuat, pegawai cenderung mengikuti arah yang ditentukan. Budaya organisasi yang lemah cenderung mengakibatkan pegawai tidak memiliki kiblat yang jelas sehingga memilih berjalan sendiri-sendiri. Akibatnya, kinerja organisasi menjadi tidak optimal. Budaya yang kuat dapat membantu kinerja organisasi karena menciptakan motivasi yang luar biasa pada diri pegawai. Perilaku dan nilai bersama yang dianut bersama membuat seseorang merasa nyaman dalam bekerja (Tjahjadi, 2001). Hasil penelitian yang dilakukan Nurjanah (2008) budaya organisasi dan gaya kepemimpinanan berpengaruh positif terhadap komitmen organisasi dan kinerja karyawan, hasil penelitian yang dilakukan oleh Soewito dan Sugiyanto (2001) menunjukkan bahwa budaya organisasi berpengaruh signifikan terhadap tercapainya kinerja karyawan yang tinggi. Hasil penelitian yang dilakukan oleh Masrukhin dan Waridin (2006) dan Yuwalliatin (2006) menunjukkan adanya pengaruh positif dari budaya organisasi terhadap kinerja karyawan. Dari penelitian tersebut budaya organisasi memberikan pengaruh yang dominan terhadap kinerja pegawai.

Dari uraian di atas, maka hipotesis yang diajukan adalah sebagai berikut :

\section{H3 : Budaya organisasi berpengaruh positif terhadap kinerja pegawai}

Mangiapane (1988) menyatakan bahwa rotasi pekerjaan menjadikan setiap pegawai mampu mengatasi setiap masalah dalan suatu pekerjaan yang membuat senioritas 
berkurang. Pegawai mendapatkan pengetahuan dan kemampuan yang mereka butuhkan untuk pekerjaan sehingga hasil yang diraih dapat lebih berkualitas. Ortega (2001) dan Mangiapane (1988) mengukur rotasi pekerjaan menggunakan beberapa faktor, yaitu tambahan kemampuan, tambahan pengetahuan, tingkat kejenuhan kerja. Campion, Cheraskin dan Stevens (1994) menyatakan bahwa organisasi menggunakan rotasi pekerjaan sebagai sarana untuk mewujudkan high performance atau kinerja yang tinggi. Campion, Cheraskin dan Stevens (1994) juga menyatakan bahwa rotasi pekerjaan adalah pergeseran suatu pekerjaan antar pegawai dalam organisasi. Pergeseran ini tidak dilakukan secara permanen. Rotasi merupakan salah satu metode untuk menempatkan atau staffing pegawai. Sundin (2001) menambahkan bahwa alasan lain dilakukannya rotasi pekerjaan adalah bahwa tugas atau pekerjaan bersifat monoton yang dilaksanakan terus menerus dapat mengakibatkan kebosanan dan penurunan hasil kerja dari pegawai. Adanya rotasi pekerjaan diharapkan dapat menstimulasi pegawai untuk mencapai kinerja yang lebih baik karena terdapat proses penambahan pengetahuan dan kemampuan pegawai, mengurangi kejenuhan kerja dari pegawai, membantu proses penempatan pegawai secara tepat, serta memberi tantangan lebih besar bagi pegawai untuk mencapai prestasi atau kinerja yang lebih baik. Hasil penelitian Santoso dan Riyadi (2012) dengan rotasi kerja, para karyawan dapat memulai dengan tugas dan fungsi dan tempat pekerjaan yang baru. Disinilah karyawan mulai belajar baik dalam tugas dan fungsi yang baru yang berbeda dengan tugas ditempatb pekerjaan sebelumnya, Indrayati (2014) bahwa rotasi berpengaruh positif dan signifikan terhadap kinerja pegawai begitu pula dengan Kaymaz (2012) Rotasi pekerjaan diperkirakan dapat memberikan kepuasan kerja dan meningkatkan produktifitas kerja yang tertinggi, karena sebagian besar menganggap rotasi pekerjaan mampu diterima sebagai metode yang efektif untuk memngembangkan keterampilan dan meningkatkan kepuasan kerja yang akhirnya berpengaruh terhadap kinerja.

Dari uraian diatas maka hipotesis yang diajukan adalah sebagai berikut :

\section{H4 : Rotasi pekerjaan berpengaruh positif terhadap kinerja pegawai}

Setiap individu dari perusahaan berasal dari latar belakang yang berbeda, oleh karena itu, perusahaan perlu melihat kebutuhan dan harapan pegawainya, bakat dan ketrampilan yang dimiliki serta bagaimana rencana pegawai tersebut pada masa mendatang. Apabila perusahaan telah mengetahui hal-hal tersebut maka akan lebih mudah untuk menempatkan pegawai pada posisi yang paling tepat sehingga pegawai akan lebih termotivasi dalam bekerja karena pada dasarnya motivasi dapat memacu pegawai untuk bekerja keras dalam mencapai tujuan mereka. Umar (1999) menyatakan bahwa motivasi adalah faktor yang kehadirannya dapat menimbulkan kepuasan kerja dan meningkatkan produktivitas atau hasil kerja dan menimbulkan berbagai perilaku manusia. Sedangkan Robbins (2006) menjelaskan bahwa kinerja seseorang dipengaruhi oleh tingkat pendidikan, inisiatif, pengalaman kerja, dan motivasi pegawai. Penelitian yang dilakukan oleh Masrukhin \& Waridin (2006) membuktikan bahwa motivasi kerja berpengaruh positif dan signifikan terhadap kinerja karyawan, namun penelitian yang 
dilakukan Murti dan Srimulyani (2013) menunjukan hasil yang berbeda yaitu motivasi tidak berpengaruh terhadap kinerja karyawan, Menurut Wibowo (2010) karyawan akan termotivasi ketika kinerja mereka akan dikenal dan dihargai. Perilaku termotivasi secara langsung dipengaruhi oleh kemampuan dan pengetahuan/keterampilan kerja individu, motivasi, dan kombinasi yang memungkinkan dan membatasi faktor konteks pekerjaan. Koesmono (2005) juga membuktikan hal yang sama tentang adanya pengaruh motivasi kerja terhadap kinerja karyawan.

Dari uraian diatas, maka hipotesis yang diajukan sebagai berikut :

\section{H5 : Motivasi kerja berpengaruh positif terhadap kinerja pegawai}

Dari hasil pustaka dan analisis terhadap bukti bukti empiris dari penelitian terdahulu maka model yang dikembangkan untuk diteliti dalam peneltian ini disajikan dalam Gambar 1

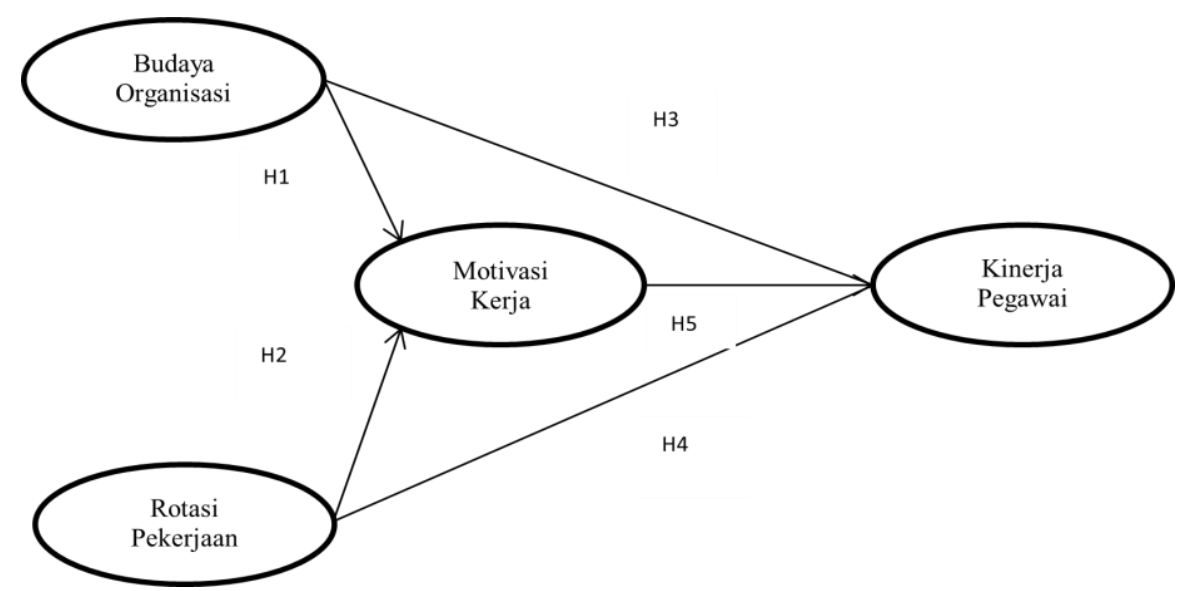

Gambar 1. Kerangka Hipotesis Penelitian

\section{METODE PENELITIAN}

Penelitian ini dimaksudkan untuk mengungkapkan gambaran mengenai pengaruh budaya organisasi, rotasi pekerjaan, dan motivasi terhadap kinerja pegawai Berdasarkan permasalahan yang diteliti, maka metode penelitian yang digunakan dalam penelitian ini adalah metode deskriptif dengan pendekatan kuantitatif yang ditunjang oleh studi kepustakaan. Dalam penelitian ini, populasi meliputi seluruh karyawan PT. Jasa Raharja (Persero) Cabang Jawa Tengah, dengan menggunakan rumus Slovin di dapatkan jumlah sampel dalam penelitian ini adalah 62 responden. Teknik pengambilan sample menggunakan teknik simple random sampling, yaitu teknik pengambilan sampel yang dilakukan secara acak sehingga seluruh populasi mempunyai kesempatan yang sama menjadi sampel. Skala interval dengan menggunakan teknik Bipolar Adjective 7 poin, caranya hanya memberikan dua kategori ekstrim yaitu sangat tidak setuju dengan sangat setuju dengan rentang skor 1-7. Uji validitas pada penelitian ini menggunakan korelasi bivariate pearson atau product moment jika $r$ hitung $>r$ tabel. Untuk uji reliabilitas dengan menggunakan uji reliabilitas internal consistencyreliability, yaitu pengujian konsistensi jawaban responden terhadap seluruh item dedalam alat ukur 
dengan metode cronbach coefisien alpha jika $\mathrm{r}$ hitung $>\mathrm{r}$ tabel dinyatakan reliable. Teknik analisis data yang digunakan adalah teknik analisis jalur dan uji sobel.

\section{HASIL PENELITIAN DAN PEMBAHASAN}

\section{Uji Validitas}

Menguji validitas kuesioner dengan mengkorelasikan setiap skor item, setiap item dibandingkan dengan R- Product Moment Pearson dengan kriteria apabila $r>0,3$ artinya item pertanyaan dikatakan valid, $\mathrm{r} \leq 0,3$ artinya item tidak valid dengan derajat kebebasan $(\mathrm{df})=\mathrm{n}-\mathrm{k}-1=60$. Analisis validitas kuesioner meliputi variable budaya organisasi (X1), rotasi pekerjaan (X2), kinerja pegawai (Y), dan motivasi kerja (Z), maka dapat diketahui hasil uji validitas kuesioner yang terlihat masing-masing item pernyataan dari variabel budaya organisasi $\left(\mathrm{X}_{1}\right)$, rotasi pekerjaan $\left(\mathrm{X}_{2}\right)$, motivasi kerja $(\mathrm{Z})$ dan kinerja pegawai (Y) mempunyai nilai korelasi yang lebih besar dari 0,3 sehingga dapat disimpulkan bahwa seluruh item tersebut valid.

\section{Uji Reliabilitas}

Reliabilitas kuesioner diperoleh dari hasil perhitungan Cronbach Alfa, dengan ketentuan apabila nilai alpha lebih besar dari 0,6. terlihat bahwa variabel budaya organisasi $\left(\mathrm{X}_{1}\right)$, rotasi pekerjaan $\left(\mathrm{X}_{2}\right)$, motivasi kerja $(\mathrm{Z})$ dan kinerja pegawai $(\mathrm{Y})$ mempunyai nilai alpha sebesar 0,$724 ; 0,690 ; 0,776$ dan 0,814. Nilai alpha tersebut lebih besar dari 0,6 sehingga dapat disimpulkan bahwa item pernyataan masing-masing variabel reliable.

\section{Deskripsi Variabel Budaya Organisasi}

Sebagian besar responden berpendapat bahwa budaya organisasi di PT Jasa Raharja cabang Jawa Tengah termasuk tinggi yaitu sebanyak 31 orang $(50,0 \%)$, dengan rata-rata sebesar 5,9 dan standar deviasi sebesar 0,70. Hal ini dikarenakan dalam membuat suatu peraturan atau norma, pimpinan melibatkan pegawai dan menyesuaian dengan keinginan pegawai serta norma-norma yang berlaku di masyarakat dan tidak melanggar hak asasi manusia. Selain itu, peraturan tersebut dilaksanakan secara konsisten, dimana pegawai yang melanggar peraturan akan menerima sanksi. Budaya organisasi yang diterapkan juga sesuai dengan misi perusahaan.

\section{Deskripsi Variabel Rotasi Pekerjaan}

Sebagian besar responden berpendapat bahwa rotasi pekerjaan di PT Jasa Raharja cabang Jawa Tengah termasuk tinggi yaitu sebanyak 45 orang $(72,58 \%)$ dan rata-rata sebesar 5,9 serta standar deviasi sebesar 0,69. Tingginya rotasi pekerjaan di PT Jasa Raharja cabang Jawa Tengah dikarenakan adanya kebijakan dari manajemen yaitu dengan dikeluarkannya Surat Keputusan Kepala Cabang Jawa Tengah SM/5/III/2017 tanggal 5 Oktober 2017 dan Surat Keputusan Kepala Cabang Jawa TengahSM/8/III/2017 tanggal 4 Desember 2017 PT. Jasa Raharja serta Surat Keputusan Kepala Cabang Jawa Tengah SM/9/III/2017 tanggal 4 Desember 2017 untuk merotasi beberapa pegawai. Tujuannya agar pegawai tidak merasa bosan, mempersiapkan manajemen kerja yang lebih baik, meningkatkan komunikasi sosial, dan meningkatkan kemampuan keterampilan dalam bekerja.

\section{Deskripsi Variabel Motivasi Kerja}

Sebagian besar responden mempunyai motivasi kerja yang termasuk sangat tinggi yaitu 
sebanyak 47 orang $(75,81 \%)$ dengan rata-rata sebesar 6,28 dan standar deviasi sebesar 0,75 . Tingginya motivai kerja karyawan PT Jasa Raharja cabang Jawa Tengah dikarenakan perusahaan memberikan kompensasi yang sesuai dengan kinerja setiap karyawan. Ditunjukkan dengan adanya pemberian insentif bagi karyawan yang mempunyai prestasi kerja baik.

Deskripsi Variabel Kinerja Pegawai

Bahwa sebagian besar responden mempunyai kinerja yang termasuk sangat tinggi yaitu sebanyak 42 orang $(67,74 \%)$ dengan rata-rata sebesar 6,1 dan standar deviasi sebesar 0,60. Tingginya kinerja karyawan PT Jasa Raharja cabang Jawa Tengah dikarenakan perusahaan memberikan motivasi kepada karyawan untuk bekerja dengan baik. Ditunjukkan dengan pencapaian target kerja oleh pegawai.

Tabel 1. Koefisien regresi variabel independen

\section{Coefficients $^{\mathbf{a}}$}

\begin{tabular}{|c|c|c|c|c|c|c|c|}
\hline \multirow{2}{*}{\multicolumn{2}{|c|}{$\begin{array}{l}\text { Mode } \\
\text { l }\end{array}$}} & \multicolumn{2}{|c|}{$\begin{array}{l}\text { Unstandardized } \\
\text { Coefficients }\end{array}$} & \multirow{2}{*}{\multicolumn{2}{|c|}{$\begin{array}{c}\begin{array}{c}\text { Standardized } \\
\text { Coefficients }\end{array} \\
\text { Beta }\end{array}$}} & \multirow[t]{2}{*}{$\mathrm{t}$} & \multirow[t]{2}{*}{ Sig. } \\
\hline & & B & Std. Error & & & & \\
\hline \multirow[t]{3}{*}{1} & (Constant) & 9.804 & 15.390 & & & .637 & .527 \\
\hline & $\begin{array}{l}\text { budaya } \\
\text { organisasi }\end{array}$ & .247 & .245 & & .112 & $\begin{array}{r}1.00 \\
9\end{array}$ & .317 \\
\hline & $\begin{array}{l}\text { rotasi } \\
\text { pekerjaan }\end{array}$ & .972 & .197 & & .549 & $\begin{array}{r}4.92 \\
5 \\
\end{array}$ & .000 \\
\hline
\end{tabular}

Dependent Variable: motivasi kerja

Sumber : Data primer terolah, 2018

Berdasarkan Tabel 1, dapat diketahui nilai $p$-value budaya organisasi sebesar $0,317>0,05$, artinya budaya organisasi tidak berpengaruh terhadap motivasi kerja. Dengan demikian Ha1 ditolak. Sedangkan rotasi pekerjaan mempunyai $p$-value sebesar $0,000<0,05$. Dengan demikian Ha2 diterima, diperoleh nilai koefisien determinasi $\left(\mathrm{R}^{2}\right)$ sebesar 0,291. Hal ini berarti bahwa 29,1\% motivasi kerja dapat dijelaskan oleh variabel budaya organisasi dan rotasi pekerjaan, sedangkan sisanya sebesar 70,9\% dipengaruhi oleh variabel lain yang tidak dimasukkan dalam model penelitian. Sedangkan besarnya koefisien jalur bagi variabel lain di luar penelitian ini adalah sebesar $(\mathrm{e} 1)=\sqrt{1-R^{2}}=$ $\sqrt{1-0,291}=0,842$. 
Tabel 2. Koefisien regresi variabel independen

\begin{tabular}{|c|c|c|c|c|c|c|c|}
\hline \multirow[t]{2}{*}{ Model } & & \multicolumn{2}{|c|}{$\begin{array}{l}\text { Unstandardized } \\
\text { Coefficients }\end{array}$} & \multirow{2}{*}{$\begin{array}{c}\begin{array}{c}\text { Standardized } \\
\text { Coefficients }\end{array} \\
\text { Beta } \\
\end{array}$} & & \multirow[t]{2}{*}{$\mathrm{t}$} & \multirow[t]{2}{*}{ Sig. } \\
\hline & & B & Std. Error & & & & \\
\hline \multirow[t]{4}{*}{1} & (Constant) & 37.858 & 10.256 & & & 3.691 & .000 \\
\hline & $\begin{array}{l}\text { budaya } \\
\text { organisasi }\end{array}$ & .162 & .164 & & .109 & .985 & .329 \\
\hline & $\begin{array}{l}\text { rotasi } \\
\text { pekerjaan }\end{array}$ & .321 & .156 & & .269 & 2.060 & .044 \\
\hline & motivasi kerja & .253 & .086 & & .376 & 2.929 & .005 \\
\hline
\end{tabular}

Dependent Variable: kinerja

Sumber: Data primer terolah,

2018

Berdasarkan tabel 2, dapat diketahui Nilai $p$ value variabel budaya organisasi sebesar 0,329 > 0,05 maka Ha diterima, artinya budaya organisasi tidak berpengaruh terhadap kinerja pegawai. Dengan demikian Ha3 ditolak. Variabel rotasi pekerjaan mempunyai p-value sebesar 0,044 $<0,05$ maka Ha ditolak, artinya rotasi pekerjaan berpengaruh terhadap kinerja pegawai. Dengan demikian Ha4 diterima.Variabel motivasi kerja mempunyai p-value sebesar 0,005 < 0,05 maka Ha ditolak, artinya motivasi kerja berpengaruh terhadap kinerja pegawai. Dengan demikian Ha5 diterima, diperoleh nilai koefisien determinasi $\left(\mathrm{R}^{2}\right)$ sebesar 0,323. Hal ini berarti bahwa 32,3\% kinerja karyawan dapat dijelaskan oleh variabel budaya organisasi, rotasi pekerjaan dan motivasi kerja, sedangkan sisanya sebesar $67,7 \%$ dipengaruhi oleh variabel lain yang tidak dimasukkan dalam model penelitian. Sedangkan besarnya koefisien jalur bagi variabel lain di luar penelitian ini adalah sebesar $(\mathrm{e} 2)=\sqrt{1-R^{2}}=\sqrt{1-0,323}=0,823$.

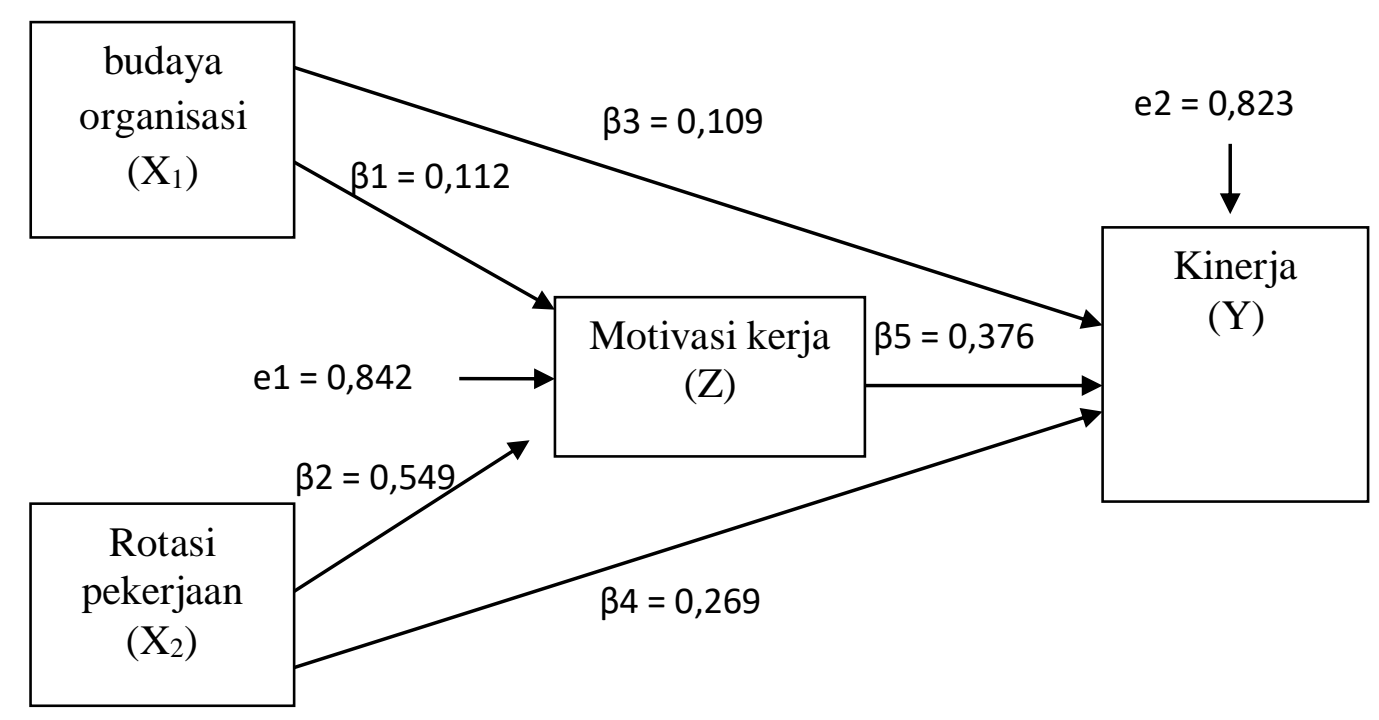

Gambar 2. Hasil Analisis Jalur 


\section{Pengaruh budaya organisasi terhadap kinerja pegawai melalui motivasi kerja}

Pengaruh langsung X1 ke $Z=\beta 1$, pengaruh variabel budaya organisasi terhadap variabel motivasi kerja adalah 0,112 atau $11,2 \%$, pengaruh langsung $\mathrm{Z}$ ke $\mathrm{Y}=\beta 5$ Pengaruh variabel motivasi kerja terhadap kinerja pegawai adalah 0,376 atau 37,6\%, pengaruh tidak langsung $\mathrm{X} 1 \mathrm{ke} \mathrm{Y}$ melalui $\mathrm{Z}=\beta 1 \times \beta 5$, pengaruh variabel budaya organisasi terhadap kinerja pegawai melalui motivasi kerja adalah $0,112 \times 0,376=0,042$ atau sebesar 4,2\%. Hasil uji path menunjukkan bahwa pengaruh langsung budaya organisasi terhadap kinerja pegawai adalah 0,109. Nilai ini lebih besar dibandingkan pengaruh tidak langsung budaya organisasi terhadap kinerja pegawai melalui motivasi kerja yang hanya sebesar 0,042. Hal ini berarti motivasi kerja tidak mampu memediasi, tapi berlaku sebagai moderasi dalam hubungan antara budaya organisasi terhadap kinerja pegawai.

\section{Pengaruh rotasi pekerjaan terhadap kinerja pegawai melalui motivasi kerja}

Pengaruh langsung X2 ke $\mathrm{Z}=\beta 2$, pengaruh variabel rotasi pekerjaan terhadap variabel motivasi kerja adalah 0,549 atau 54,9\%. Pengaruh langsung $\mathrm{Z}$ ke $\mathrm{Y}=\beta 5$, pengaruh variabel motivasi kerja terhadap kinerja pegawai adalah 0,376 atau 37,6\%. Pengaruh tidak langsung X2 ke Y melalui $\mathrm{Z}=\beta 2 \times \beta 5$, pengaruh variabel rotasi pekerjaan terhadap kinerja pegawai melalui motivasi kerja adalah $0,549 \times 0,376=0,206$ atau sebesar 20,6\%. Hasil uji path menunjukkan bahwa pengaruh langsung rotasi pekerjaan terhadap kinerja pegawai adalah 0,269 . Nilai ini lebih besar dibandingkan pengaruh tidak langsung rotasi pekerjaan terhadap kinerja pegawai melalui motivasi kerja yang hanya sebesar 0,206. Hal ini berarti motivasi kerja tidak mampu memediasi, tapi berlaku sebagai moderasi dalam hubungan antara rotasi pekerjaan terhadap kinerja pegawai.

\section{Uji Sobel Budaya Organisasi Terhadap Kinerja Pegawai dengan Motivasi Kerja sebagai Variabel Moderasi}

Nilai Z dari sobel test tidak dapat dihasilkan langsung dari hasil regresi tetapi dengan perhitungan manual dengan rumus sebagai berikut:

$$
\begin{aligned}
& \mathrm{z}=\frac{a b}{\sqrt{\left(b^{2} S E_{a}^{2}\right)+\left(a^{2} S E_{b}^{2}\right)}} \\
& z=\frac{0,029 x 0,350}{\sqrt{\left(0,350^{2} 0,284^{2}\right)+\left(0,029^{2} 0,074^{2}\right)}} \\
& \mathrm{z}=\frac{0,01015}{0,00988}=1,027
\end{aligned}
$$

Dari hasil perhitungan di atas diperoleh nilai $\mathrm{z}$ sebesar 1,027 , karena nilai $\mathrm{z}$ yang diperoleh sebesar 1,027 < 1,98 dengan tingkat signifikansi 5\% maka membuktikan bahwa motivasi tidak mampu memediasi hubungan budaya organisasi terhadap kinerja.

Uji Sobel Rotasi Pekerjaan Terhadap Kinerja Pegawai dengan Motivasi Kerja sebagai Variabel Moderasi

Nilai Z dari sobel test tidak dapat dihasilkan langsung dari hasil regresi tetapi dengan perhitungan manual dengan rumus sebagai berikut: 


$$
\begin{aligned}
& \mathrm{z}=\frac{a b}{\sqrt{\left(b^{2} S E_{a}^{2}\right)+\left(a^{2} S E_{b}^{2}\right)}} \\
& z=\frac{0,936 \times 0,350}{\sqrt{\left(0,350^{2} 0,194^{2}\right)+\left(0,936^{2} 0,074^{2}\right)}} \\
& \mathrm{z}=\frac{0,3276}{0,8761}=0,374
\end{aligned}
$$

Dari hasil perhitungan di atas diperoleh nilai $\mathrm{z}$ sebesar 0,374 , karena nilai $\mathrm{z}$ yang diperoleh sebesar 0,374 <1,98 dengan tingkat signifikansi 5\% maka membuktikan bahwa motivasi tidak mampu memediasi hubungan rotasi pekerjaan terhadap kinerja.

\section{PEMBAHASAN}

\section{Pengaruh Budaya Organisasi terhadap Motivasi Kerja}

Berdasarkan hasil analisis data menggunakan analisis jalur diperoleh hasil bahwa budaya organisasi tidak berpengaruh terhadap motivasi kerja. Hal ini menunjukkan bahwa budaya organisasi yang kondusif yang diterapkan di PT Jasa Raharja Cabang Jawa Tengah belum tentu dapat meningkatkan motivasi kerja pegawainya. Kondisi ini disebabkan pimpinan masih kurang bersedia untuk membagikan ide-ide yang kreatif kepada pegawainya dalam menunjang pekerjaan, akibatnya pegawai mempunyai kecenderungan tidak mempunyai kreatifitas dalam bekerja sehingga cenderung bermalas-malasan dalam bekerja. Selain itu, sebagai BUMN, PT Jasa Raharja sudah mempunyai peraturan yang baku sejak dahulu. Dengan kata lain, PT Jasa Raharja mempunyai norma-norma yang cenderung tetap sejak dahulu, belum ada pembaharuan, sehingga tidak terlalu berpengaruh terhadap motivasi kerja pegawai. Kondisi ini membuat budaya organisasi tidak terlalu memberikan dampak yang nyata pada motivasi kerja karyawan. Hasil penelitian ini tidak sesuai dengan penelitian sebelumnya yang menunjukkan bahwa budaya organisasi memiliki pengaruh positif dan signifikan terhadap motivasi.

\section{Pengaruh Rotasi Pekerjaan terhadap Motivasi Kerja}

Berdasarkan hasil analisis data menggunakan analisis jalur diperoleh hasil bahwa rotasi pekerjaan berpengaruh terhadap motivasi kerja dimana dengan rotasi pegawai dapat meningkatkan produktivitas kerja karena pegawai yang sudah lama bekerja dalam satu bagian akan merasa bosan dan jenuh, oleh karena itu perpindahan ke bagian lain akan meningkatkan produktivitas kerja karena pegawai mendapat semangat baru di tempat kerja yang baru dengan tugas yang baru, sehingga motivasi kerja pegawai juga akan meningkat. Hubungan kerja antara seorang pegawai dengan pegawai lainnya dalam satu bagian terkadang diwarnai perselisihan yang dapat membuat seorang pegawai merasa tidak nyaman dalam bekerja sehingga motivasi kerjanya menurun. Dengan adanya rotasi pegawai maka akan mengurangi perselisihan sehingga dapat meningkatkan motivasi kerja karena pegawai merasa nyaman bekerja dengan orang-orang yang baru. Hasil penelitian ini sesuai dengan penelitian Ortega (2001), Praningrum (2002), Juwita (2010), Rachmawati (2011) menunjukkan rotasi pekerjaan berkontribusi langsung 
terhadap motivasi kerja. Dimana pada penelitian tersebut rotasi memberikan pengaruh yang dominan terhadap motivasi kerja karyawan.

\section{Pengaruh Budaya Organisasi terhadap Kinerja Pegawai}

Berdasarkan hasil analisis data menggunakan analisis jalur diperoleh hasil bahwa budaya organisasi tidak berpengaruh terhadap kinerja pegawai. Hal ini terlihat pada konsistennya peraturan yang ada di dalam perusahaan sejak dahulu sampai sekarang, pembuataan peraturan yang sesuai norma-norma yang berlaku dan misi yang ada di perusahaan juga tidak mengalami perubahan signifikan, serta keterlibatan pegawai dalam pembuataan peraturan. Kondisi ini membuat budaya organisasi tidak terlalu memberikan dampak yang nyata pada kinerja karyawan.Artinya, budaya organisasi bukan variabel yang bisa menjelaskan kinerja pegawai. Dampaknya akan menurunkan kinerja pegawai. Hasil penelitian ini sesuai dengan Lina (2014) yang menunjukkan bahwa budaya organisasi tidak berpengaruh signifikan terhadap kinerja pegawai.

\section{Pengaruh Rotasi Pekerjaan terhadap Kinerja Pegawai}

Berdasarkan hasil analisis data menggunakan analisis jalur diperoleh hasil bahwa rotasi pekerjaan berpengaruh terhadap kinerja pegawai. Semakin tinggi rotasi pekerjaan maka kinerja pegawai juga akan semakin tinggi. Sebaliknya, semakin rendah rotasi pekerjaan maka kinerja pegawai juga akan rendah. Dengan adanya rotasi pekerjaan maka setiap pegawai mampu mengatasi setiap pekerjaan yang membuat senioritas berkurang. Pegawai mendapatkan pengetahuan dan kemampuan yang mereka butuhkan untuk pekerjaan sehingga hasil yang diraih dapat lebih berkualitas. Rotasi pekerjaan sebagai sarana untuk mewujudkan highperformance atau kinerja yang tinggi. Pergeseran ini tidak dilakukan secara permanen. Rotasi merupakan salah satu cara untuk menempatkan atau staffing pegawai.

Rotasi pekerjaan juga bertujuan agar pekerjaan bersifat monoton yang dilaksanakan terus menerus dapat mengakibatkan kebosanan dan penurunan hasil kerja dari pegawai. Hasil penelitian ini menunjukkan bahwa rotasi pekerjaan berpengaruh terhadap kinerja pegawai. Hasil penelitian ini sesuai dengan penelitian Nurlatifah (2009), Putri (2013), Indrayati (2014) juga menunjukkan bahwa rotasi berpengaruh posistif terhadap kinerja pegawai.

\section{Pengaruh Motivasi Kerja terhadap Kinerja Pegawai}

Berdasarkan hasil analisis data menggunakan analisis jalur diperoleh hasil bahwa motivasi kerja berpengaruh terhadap kinerja pegawai. Semakin tinggi motivasi kerja maka kinerja pegawai juga akan semakin tinggi. Sebaliknya, semakin rendah motivasi kerja maka kinerja pegawai juga akan rendah. Penelitian ini membuktikan bahwa motivasi mempengaruhi kinerja pegawai. Hal ini terlihat dari hasil angket yang menunjukkan bahwa motivasi pegawai bekerja adalah untuk mencapai prestasi kerja, untuk memperoleh pengaruh, untuk mengendalikan orang lain, menurunkan ketergantungan dari orang lain dan memperluas atau meningkatkan jenjang jabatan. Penelitian ini sesuai dengan penelitian yang dilakukan oleh Masrukhin \& Waridin 
(2006), Ummah (2011), Athiyah (2011), dan Zikry (2012) dan Koesmono (2015) membuktikan bahwa motivasi kerja berpengaruh terhadap kinerja karyawan.

\section{KESIMPULAN}

Berdasarkan hasil penelitian dan analisis secara keseluruhan, penulis dapat mengambil kesimpulan sebagai berikut. Budaya organisasi tidak berpengaruh terhadap motivasi kerja dan kinerja karyawan PT. Jasa Raharja Cab. Jawa Tengah. Rotasi pekerjaan berpengaruh terhadap motivasi kerja dan kinerja karyawan PT. Jasa Raharja Cab. Jawa Tengah. Motivasi kerja berpengaruh terhadap kinerja pegawai PT. Jasa Raharja Cab. Jawa Tengah.

\section{IMPLIKASI MANAJERIAL}

Implikasi yang dapat dikemukakan yang mempengaruhi kinerja pegawai PT Jasa Raharja cabang Jawa Tengah, baik secara langsung maupun tidak langsung yaitu rotasi pekerjaan dan motivasi kerja. Rotasi pekerjaan sangat diperlukan dalam suatu organisasi. Hal ini digunakan untuk mengurangi kebosanan, mempersiapkan karyawan untuk sistem manajemen yang lebih baik, meningkatkan produktivitas, dan meningkatkan pengetahuan dan keterampilan. Rotasi pekerjaan juga dapat meningkatkan motivasi kerja pegawai yang pada akhirnya dapat meningkatkan kinerja pegawai. Rotasi pekerjaan dapat dilakukan dengan divergensi aktivitas pegawai, mempromosikan seorang pegawai untuk menduduki jabatan di bagian lain atau memindahkan tugas pegawai ke daerah atau cabang lainnya.

Dalam penelitian ini motivasi kerja mempunyai peran yang sangat besar terhadap kinerja pegawai. Pimpinan PT. Jasa Raharja Cab. Jawa Tengah dapat meningkatkan motivasi kerja pegawai melalui peningkatkan prestasi kerja, memberikan pengaruh, pengendalian, ketergantungan dan perluasan. Kinerja pegawai digunakan untuk mengetahui produktivitas kerja karyawan. Selayaknya kinerja pegawai diukur secara kontinue untuk mengetahui prestasi kerja pegawai. Kinerja pegawai dapat diukur dengan melihat aspek-aspek standar pekerjaan yang meliputi aspek kualitatif dan aspek kuantitatif. Pimpinan PT. Jasa Raharja Cab. Jawa Tengah dapat meningkatkan kinerja pegawainya melalui kerjasama, tanggung jawab dan kecakapan, sikap, kreativitas, kejujuran, inisiatif, keandalan, kesetiaan dan kepemimpinan.

\section{SARAN BAGI PENELITIAN SELANJUTNYA}

Saran bagi institusi adalah meningkatkan kualitas rotasi pekerjaan, yaitu dengan meningkatkan produktivitas, menciptakan kesimbangan antara tenaga dengan komposisi jabatan, menambah pengetahuan pegawai, memberikan perangsang kepada pegawai untuk meraih karir yang lebih tinggi, melaksanakan sanksi, mendorong pegawai untuk melakukan persaingan secara terbuka, menyesuaikan pekerjaan dengan kondisi fisik karyawan dan mengatasi perselisihan antar pegawai.

Keterbatasan penelitian ini tidak berhasil membuktikan bahwa variabel motivasi kerja mampu memediasi hubungan rotasi pekerjaan dengan kinerja pegawai, namun bertindak sebagai variabel moderasi dalam hubungan antara rotasi pekerjaan 
terhadap kinerja pegawai. Demikian juga pengaruh antara budaya organisasi terhadap kinerja pegawai tidak mampu dimediasi oleh motivasi kerja. Saran bagi penelitian selanjutnya mengenai pengaruh budaya organisasi dan rotasi kerja terhadap motivasi kerja untuk meningkatkan kinerja pegawai masih mungkin untuk dikembangkan yaitu dengan menambahkan variabel kepuasan kerja ,untuk sasaran objek penelitian lebih diutamakan kepada karyawan yang sudah pernah di rotasi agar data yang didapat lebih akurat.

\section{DAFTAR PUSTAKA}

Abbasi, B and Saravani, S.R. 2013. Investigating The Influence of Job Rotation on Performance By Considering Skill Variation and Job Satisfaction of Bank Employee's. Technical Gazette 20 No.3 : 473-478

Adjei, D. 2012. The Impact of Job Relation on Employee's Performance A Case Study : Utrak Financial Services Limited. Master Business Administration : University of Science And Technology

As'ad, Moh. 2011. Psikologi Industri: Seri Ilmu Sumberdaya Manusia. Edisi 4, Yogyakarta: Liberty

Bambang Tjahjadi, 2001. Konsep Budaya Organisasi, Kesenjangan Budaya Organisasi dan Pengaruhnya terhadap Kinerja Organisasi. Majalah Ekonomi, Th. XI, No.1

Brahmasari, Ida Ayu. \& Suprayetno, Agus. 2008. Pengaruh Motivasi Kerja, Kepemimpinan dan Budaya Organisasi Terhadap Kepuasan Kerja Karyawan serta Dampaknya Pada Kinerja Perusahaan. Jurnal Manajemen dan Kewirausahaan, Vol.10 No.2.Surabaya: Universitas 17 Agustus Surabaya

Campion, Michael A, Cheraskin, Lisa, Stevens, Michael J. 1994. Career-Related Antecedents and Outcomes Of Job Rotation. Academy of Management Journal, Vo. 37 No.6

Denison and Misra. 1995. Toward Of Organizational Culture and Effectiveness. Organization Science, Vol.6, No.2, March-April.

Dwi Suhartono dan Sri Raharso. 2003. Transfer Pelatihan : Faktor Apa Yang Paling Mempengaruhi?. Kajian Bisnis STIE Widya Wiwaha Yogyakarta, No. 28

Dwiyanto, Agus. 2006. Mewujudkan Good Governance Melayani Publik.Yogyakarta: Gadjah Mada University

Eny Rahmani, 2003. Perubahan Budaya Organisasi : Suatu Alternatif Strategi Menghadapi Masa Depan. Jurnal Bisnis dan Manajemen, Vol. 3, No. 2

Fatmawati, Mahdani, sofyan Idris. 2012 . Pengaruh Budaya Organisasi dan Rotasi Pekerjaan terhadap Motivasi Kerja serta Implikasinya pada Kinerja Pegawai Arraniry Banda Aceh.

Flippo, Edwin B. 1993. Manajemen Personalia. Edisi Keempat. Penerbit Erlangga 
Fuad Mas'ud. 2004. Survai Diagnosis Organisasional. Konsep dan Aplikasi, Badan Penerbit Universitas Diponegoro, Semarang

Furnham, Adrian and Gunter, Barrie. 1993. Organizational behavior, Corporate culture, Employee attitude surveys, Auditing, Handbooks, manuals, etc. London: Routledge.

Giantari dan Riana. 2017. Pengaruh Budaya Organisasi terhadap Motivasi Kerja dan Kinerja Karyawan Klumpu Bali Resort Sanur. e-journal Manajemen Unud. 6(2)

Gibson, I and Donnelly. 1997. Organizations Behaviour, Structure, Processes. 9Ed, Richard D. Irwin Inc

Grenberg dan Baron. 2000. Assesing Construct Validity in Organizational Research, Administrative Scince Quartely

Hasibuan, H. Malayu S.P. 2008. Manajemen Sumber Daya Manusia. Edisi Revisi. PT. Bumi Aksara. Jakarta

Hasibuan, Malayu S. P. 2012. Manajemen Sumber Daya Manusia. Cetakan Keenam belas. Jakarta: PT. Bumi Aksara

Handoko, T.Hani. 2003. Manajemen Personalia dan Sumber Daya Manusia. Yogyakarta, BPFE-Yogyakarta

Henry, Simamora. 2010. Manajemen Sumber Daya Manusia. Edisi ke-1, Cetakan Kedua, Yogyakarta: Bagian Penerbitan STIE YKPN

H. Teman Koesmono. 2005. Pengaruh Budaya Organisasi terhadap Motivasi dan Kepuasan Kerja serta Kinerja pegawai pada Sub Sektor Industri Pengolahan Kayu Skala Menengah di Jawa Timur. Jurnal Manajemen \& Kewirausahaan, Vol.7, No. 2.

Indrayati, M. Aprilia. 2014. Analisis Pengaruh Rotasi Pekerjaan dan Motivasi Kerja terhadap Kinerja Karyawan melalui Kepuasan Kerja pada PT Bank Tabungan Negara (Persero) Tbk Kantor Cabang Semarang. Skripsi. Universitas Diponegoro Semarang

Juwita, Kristin. 2010. Analisis Rotasi Pekerjaan, Komunikasi Organisasi Dan Pengaruhnya Terhadap Kinerja Melalui Kepuasan Kerja Karyawan (Studi PadaRumah Sakit Islam Malang). Malang : Program Pascasarjana Fakultas Ekonomi dan BisnisUniversitas Brawijaya

Kaymaz. 2010. The Effect of Job Rotation Practices on Motivation : A research on Managers in the Automotive Organizations. Business and Economics Research Journal, Vol.1, No.3

Kinman, Gail and Kinman, Russell. 2001. The Role of Motivation to Learn in Management Education. Journal of Workplace Learning, Vol. 3, No. 4

Lina, Dewi. 2014. Analisis Pengaruh Kepemimpinan dan Budaya Organisasi terhadap Kinerja Pegawai dengan Sistem Reward sebagai Variabel Moderating: Pegawai 
Bieo UMSU Universitas Muhammadiyah Sumatera Utara. Jurnal Riset Akuntansi dan Bisnis.

Maharani. 2013. Pengaruh Insentif, Kedisiplinan, dan Kepemimpinan Terhadap Kinerja Karyawan Di KSP Karya Niaga Gajah Demak Kudus: Skripsi Progam Studi Manajemen Fakultas Ekonomi Universitas Muria Kudus

Mahmudi. 2007. Manajemen Kinerja Sektor Publik. Yogyakarta: Sekolah Tinggi Ilmu Manajemen YKPN

Mansur. 2009. Analisis pengaruh Budaya Organisasi dan Rotasi Pekerjaan terhadap Motivasi Kerja untuk Meningkatkan Kinerja Pegawai Direktorat Jenderal Pajak. Tesis Program Pascasarjana. Universitas Diponegoro. Semarang

Mangkunegara A. Prabu. 2006. Evaluasi Kinerja SDM. Bandung: PT. Refika Aditama

Mangiapane, Adele R. 1988. Empowering People To Improve a Process. Manufacturing Systems, Vol. 6, No. 1

Mansur. 2009. Analisis Pengaruh Budaya Organisasi dan Rotasi Pekerjaan terhadap Motivasi Kerja untuk Meningkatkan Kinerja Pegawai Ditjen Pajak. Tesis Program Pascasarjana Universitas Diponegoro

Masrukhin dan Waridin. 2006. Pengaruh Motivasi Kerja, Kepuasan Kerja, Budaya Organisasi dan Kepemimpinan terhadap Kinerja Pegawai. Jurnal Ekonomi \& Bisnis, Vol. 7, No. 2

Mayangsari, Lia. 2013. Pengaruh Pemberian Insentif terhadap kinerja Di departemen Penjualan PT PUSRI. Palembang

Nugroho, Rakhmat. 2006. Analisis Faktor-Faktor Yang Mempengaruhi Kinerja Karyawan Studi Empiris Pada PT. Bank Tabungan Negara (Persero) Cabang Bandung. Tesis. Magister Manajemen Universitas Diponegoro

Nurjanah. 2008. Pengaruh Gaya kepemimpinanDanBudaya organisasi Terhadap Komitmen Organisasi Dalam Meningkatkan Kinerja Karyawan (Studi Pada Biro Lingkup Departemen Pertanian). Program Studi Magister Manajemen,Universitas Diponegoro, Semarang

Nurlatifah. 2009. Pengaruh Rotasi Kerja terhadap Kinerja Pustakawan di Perpustakaan Universitas Gadjah Mada Yogyakarta.

Ofner, J. Alan. 1987. Keeping Your High Achievers Motivated. Management Solutions, Vol.32, No.7

Ortega, Jaime. 2001. Job Rotation as a Learning Mechanism. Management Science, Vol.47 No.10

Praningrum. 2002. Pengaruh Praktek Manajemen Sumber Daya Manusia Terhadap Komitmen Pimpinan Pada Kualitas Di Rumah Sakit Kota Bengkulu. Jurnal Ekonomi dan Bisnis, No. 3, p. 156-165.

Prihayanto, Susandi. \& Ratnawati, Intan. 2011. Pengaruh Budaya Organisasi dan Motivasi Terhadap Kinerja Karyawan. Jurnal skripsi Susandi Prihayanto. 
Pulich, Marcia Ann. 1989. Revitalizing an Employee's Job Interest. Supervisory Management, Vol. 34. No. 3

Putu Sunarcaya. 2008. Analisis Faktor-Faktor yang Mempengaruhi Kinerja Pegawai Di Lingkungan Dinas Kesehatan Kabupaten Alor Nusa Tenggara Timur. Tugas Akhir Program Magister (TAPM). Universitas Terbuka Jakarta

Putri, Putu Ayu Cintya Permata. 2013. Analisis Pengaruh Rotasi Pekerjaan dan Pengembangan Karir terhadap Motivasi dan Kinerja Karyawan pada PT Bank Jatim cabang Jember. Skripsi. Universitas Jember

Rafferty, A and Griffin, M. 2004. Dimensions of transformational leadership: Conceptual and empirical extension The Leadership. Quarterl 15, 329-354

Rahmanda, Faldian Putra. 2013. Pengaruh Insentif terhadap Motivasi dan Kinerja Karyawan (Studi pada Karyawan PT. Jamsostek (Persero) Cabang Malang). Jurnal Administrasi Bisnis, Vol. 3 No. 2.

Rachmawati. 2011. Pengaruh Budaya Organisasi, Gaya Kepemimpinan dan Motivasi Kerja terhadap Kinerja Dosen di Universitas Sultan Ageng Tirtayasa. e-journal Untirta. 2(1)

Ratnawati, Intan dan Prihayanto, S. 2011. Pengaruh Budaya Organisasi dan Motivasi terhadap Kinerja Karyawan. Skripsi. Undip Semarang

Rivai, Veithzal. 2001. Beberapa Upaya Untuk Meningkatkan Motivasi Kerja Profesional Staf ( Survei di Bank Pemerintah Bank Mandiri., Bank BRI, Bank BRI dan Bank BTN tahun 2000). Jurnal Ekonomi Perusahaan.

Robbins, S.P. 2003. Organizational Behaviour Concept, Contoversiest, Applications, 6Ed, Prentice Hall, Inc. Eaglewood, Cliff, New Jersey

Robbins, S.P, 2006, Perilaku Organisasi, Edisi 10, PT. Indeks Kelompok Gramedia

Robbins Stephen P. 2010. Perilaku Organisasi. Jilid 1 \& 2, Alih Bahasa : Hadyana Pujaatmaka, Indeks Kelompok Gramedia, Jakarta.

Robbins, Stephen P \& Judge, Timothy A. 2013. Organizational Behavior Edition 15. New Jersey: Pearson Education

Robbins, S.P. 2008. Organizational Behaviour. (Perilaku Organisasi Edisi Ke Sepuluh. Alih Bahasa Drs. Benyamin Molan. Jakarta: macanan Jaya Cemerlang

Simamora, Henry. 2004. Manajemen Sumber Daya Manusia. Yogyakarta: SIE YKPN

Sitty Yuwalliatin. 2006. Pengaruh Budaya Organisasi, Motivasi dan Komitmen Terhadap Kinerja Serta Pengaruhnnya Terhadap Keunggulan Kompetitif Dosen Unissula Semarang. Jurnal Ekonomi dan Bisnis, Vol.7 No.2, Juli,p.241-256

Stoner, et.al. 1996. Manajemen. Alih Bahasa. Jilid 1 \& Jilid 2. Jakarta: Simon \& Schuster (Asia Pte. Ltd.) 
Pengaruh Budaya Organisasi dan Rotasi Pekerjaan Terhadap Motivasi Kerja Untuk Meningkatkan Kinerja Pegawai

Suharto dan Budhi Cahyono. 2005. Pengaruh Budaya Organisasi, Kepemimpinan dan Motivasi Kerja Terhadap Kinerja Sumber Daya Manusia di Sekretariat DPRD Propinsi Jawa Tengah. Jurnal Riset \& Bisnis Indonesia, Vol.1, No 1 